Scientific Review - Engineering and Environmental Sciences (2021), 30 (3), 485-495

Sci. Rev. Eng. Env. Sci. (2021), 30 (3)

Przegląd Naukowy - Inżynieria i Kształtowanie Środowiska (2021), 30 (3), 485-495

Prz. Nauk. Inż. Kszt. Środ. (2021), 30 (3)

http://iks.pn.sggw.pl

DOI 10.22630/PNIKS.2021.30.3.41

Noora SAAD ${ }^{1}$, Samara AI-DULAIMI ${ }^{2}$

${ }^{1}$ Al-Nahrain University, College of Engineering

${ }^{2}$ University of Zakho, Faculty of Science

\title{
Removal of Meropenem by using Lemna minor
}

Key words: kinetic models, biodegradation, Lemna minor, Meropenem

\section{Introduction}

Rapeutic drugs are a class of anthropogenic substances that are an emerging issue about pollution of the environment. Antibiotics are therapeutic organic compounds that can be produced by particular microorganisms as secondary metabolites, or can be generated artificially or semi-artificially (Phillips, 2003). Antibiotics exert antibacterial activity by altering the basic metabolic pathways of bacteria (Girardi et al., 2011).

These compounds are commonly used in human medicine for the prevention of bacterial infections, in agriculture for the fight against plant pathogens, in the veterinary industry and in aquaculture for the control of pathogenic agents. Antibiotics, however, are also used as growth promoters (Nunes, Veiga, Frankenbach, Serôdio \& Pinto, 2019).

This number contains both human and veterinary antibiotics, most of which are antibiotics for veterinary purposes (Thiele-Bruhn, 2003). For all the reasons previously studied, the increasing concentration of antibiotics in the environment resulted from the increased use of such products.

Although not present in high concentrations, widespread dissemination of such materials has recently been observed, particularly in the aquatic environment. Generally, urine and feces are the primary sources of unchanged types of prescription drugs in nature after the excretion of pharmaceutical materials. This helps, with or without treatment, these chemicals to enter waste water (Nunes et al., 2019).

In certain countries, excrete-containing waste water and drug residues are processed at wastewater treatment 
plants where they can be contaminated or absorbed by sludge treatment (Faisal, Nassir, Naji, Naushad \& Ahamad, 2020; Naji, Faisal, Rashid, Naushad \& Ahamad, 2020; Rahi et al., 2020; Saad, Abd Ali, Naji, Faisal \& Al-Ansari, 2020). The danger of such pharmaceuticals is subjected to the surface when the contaminated wastewater is not treated successfully or not treated at all (Karthikeyan \& Meyer, 2006; Alshammari et al., 2020).

Many engineering developments, including coagulation, floatation, chemical reduction, oxidation, photochemical degradation, and microbial remediation, have been proposed to address these issues by eliminating antibiotics from habitats (Abd Ali et al., 2020; Ahmed, Naji, Faisal, Al-Ansari \& Noushad, 2020; Naji, Jassam, Yaseen, Faisal \& Al-Ansari, 2020).

The utility of plants has grown over the years in the biological remediation of pollutants. In the literature, many plant species with the ability to eliminate a wide range of environmental pollutants have been recorded (Sekulic et al., 2019; Ahmed, Faisal, Jassam, Naji \& Naushad, 2020; Naji, Jassam et al., 2020).

The one given by Zhao et al. (2010) in which Lemna minor was tested is another example of using plants to mitigate the impact of pharmaceuticals in practical circumstances. The plant showed a strong response to large amounts of both absorbing and metabolizing pharmaceuticals. The conditions in which the plants have been tested are made as similar as possible to the environmental conditions under which they will be subjected. Therefore, the objective of this research is to study the photototoxicity of Meropenem on Lemna minor for different Meropenem concentrations from 1 June 2020 to 15 July 2020.

\section{Material and methods}

\section{Lemna minor}

In Steinberg medium, Lemna minor cultures were produced in controlled laboratory conditions at $25 \pm 2{ }^{\circ} \mathrm{C}$. The plant was subjected to continuous light to tolerate to the new environment for five days prior to the beginning of the test in order to allow plant acclimatization to the conditions needed by the adopted test guidelines. The Lemna minor was subsequently exposed to a series of three concentrations of Meropenem for five days. Meropenem standard stock solutions have been prepared in water at a concentration of $1,000 \mathrm{mg} \cdot \mathrm{L}^{-1}$ and held in amber screw-capped glass vials in darkness at a temperature of $20^{\circ} \mathrm{C}$ for a period of seven days (Faisal, Al-Wakel, Assi, Naji \& Naushad, 2020).

The concentrations selected were $0.01,0.05$, and $0.1 \mathrm{mg} \cdot \mathrm{L}^{-1}$. The operation process was based on the operation of the built wetland as batch reactors for different influencer concentrations for the period from 1 June 2020 to 15 July 2020 as previously mentioned. The batch experiments were carried out with a period of detention equal to five days. At the Ministry of Science and Technology, the sample concentration of water was measured. Liquid samples were obtained and the Meropenem was centrifuged and musurified using highperformance liquid chromatography (HPLC). 


\section{Results and discussion}

The removal efficiencies for different initial concentrations $(0.01,0.05$, and $0.1 \mathrm{mg} \cdot \mathrm{L}^{-1}$, respectively) of Lemna spp. $\mathrm{CW}$ are shown in Figure 1. Each concentration was tracked for two months in this figure (from June 1st to July 31st). To take the readings, a check point was set every two weeks. At each check point, the readings were taken as five-day shipments (the check points assigned were June 1st, June 15th, July 1st, and July 15 th). For better clarification, each initial concentration was placed into a separate figure.

Removal efficiencies have shown that the detention period has risen from one day to five days. The removal efficiency values for Lemna spp. samples for the first period (1 June 2020) were $83.1,85.1,86.3,87.4$ and 88.4 for the first period (1 June 2020) and 57.4, 58.4, $61.5,62.5$ and 63.5 (15 July 2020) for the last period, corresponding to $0.1 \mathrm{mg} \cdot \mathrm{L}^{-1}$ for each period and initial concentration, respectively.

The efficiency of the Lemna spp. system was very good, with overall removal efficiencies ranging from $58.4 \%$ for Meropenem to $88.4 \%$ for both under low concentration. The removal efficiency values for Lemna spp. samples were 88.4 for the first period and 63.5 for the last period corresponding to the 5 th and the initial concentration was $0.1 \mathrm{mg} \cdot \mathrm{L}^{-1}$, compared with the removal efficiency of Meropenem for the first and last periods for the last day (5th). In this analysis, as the concentration used, the decrease in removal efficiency reported in Lemna spp. systems could also be attributed to that toxic effect.
The removal efficiency values for Lemna spp. samples decreased from 95.3 to 88.4 relative to the removal efficiency of Meropenem when the initial concentration rose from 0.01 to $0.1 \mathrm{mg} \cdot \mathrm{L}^{-1}$ for the first cycle and the last day (5th), respectively. These findings indicate that the content of Meropenem medium in the plant continues to increase. In duckweed, high doses of Meropenem induce the synthesis of few metabolites (starch, protein, polypeptic, etc.) that could lead to excess biomass in such configurations. Few previous workers have also documented the physiological alternation and inhibition of enzymatic pathways in plants subjected to elevated Meropenem load, indicating the adverse effect of elevated Meropenem content on the functioning of the plan (Białk-Bielińska et al., 2018).

To run the system at the optimal scale, the load in the duckweed-based phytoremediation system should be optimized (Verma \& Suthar, 2015). The results confirmed that the presence of Lemna spp. in the units for adopted concentrations would increase the reduction of Meropenem because Lemna spp. will provide the required environment for phytoremediation growth within the root zone and other parts of Lemna spp. (Kouki, M'hiri, Saidi, Belad'd \& Hassen, 2009). Plants have a photosystem responsible for light harvesting and energy transfer to the act (Baker 2008; Faisal, Alquzweeni, Naji \& Naushad, 2020). Bacteria was also reduced in contamination level. This could be as a result of biochemical activities of the indigenous microbes within the wastewater which tend to use up the pollutants in the wastewater (Rakhshaee, Giahi \& Pourahmad, 2009). 
a) Concentration $=0.01 \mathrm{mg} \cdot \mathrm{L}^{-1}$

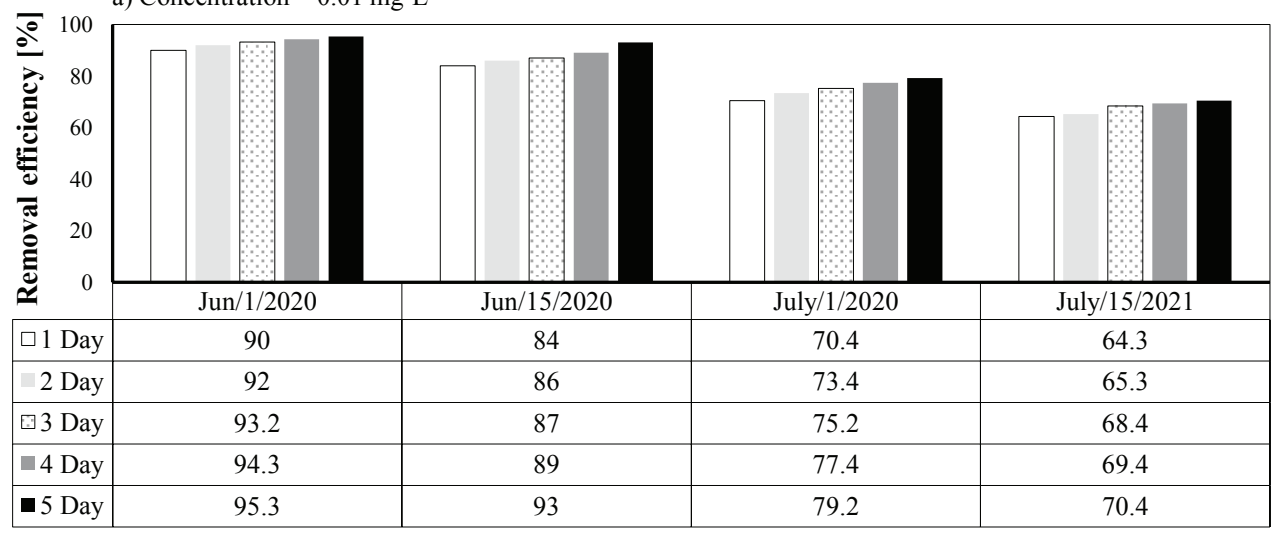

b) Concentration $=0.05 \mathrm{mg} \cdot \mathrm{L}^{-1}$

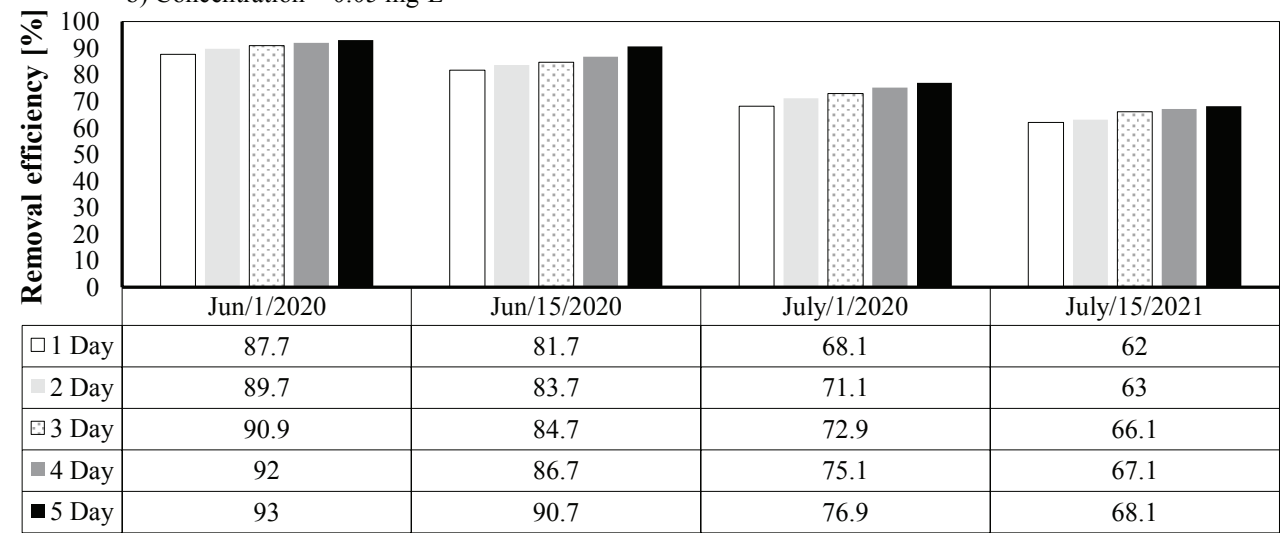

c) Concentration $=0.1 \mathrm{mg} \cdot \mathrm{L}^{-1}$

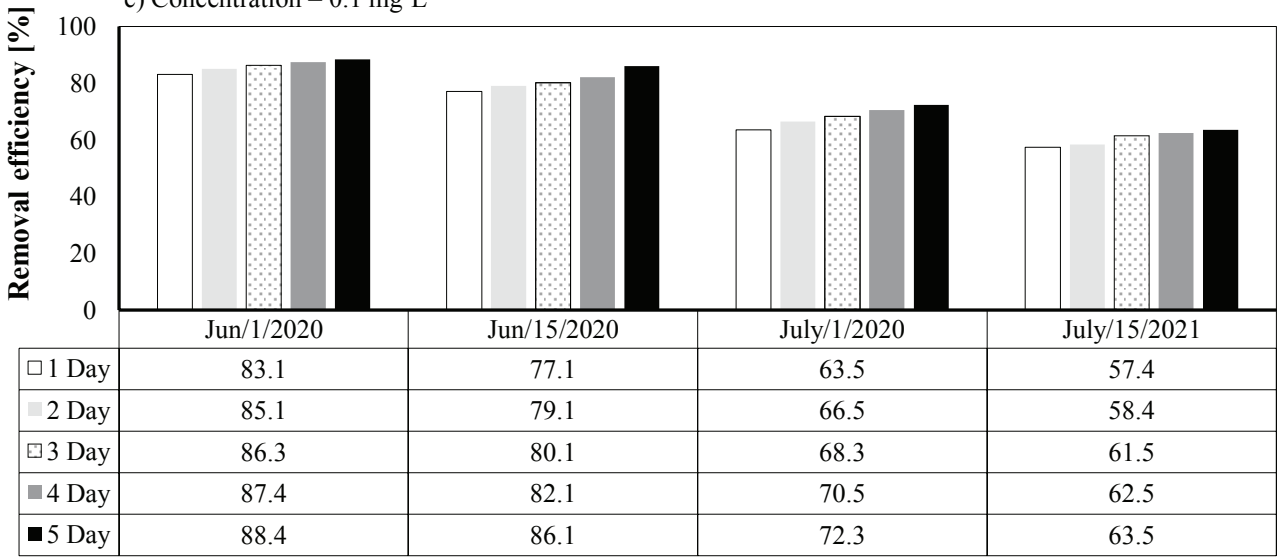

FIGURE 1. Constant initial concentration $\left(0.01,0.05\right.$ and $\left.0.1 \mathrm{mg} \cdot \mathrm{L}^{-1}\right)$ removal efficiencies of Meropenem in CW of Lemna spp. 
These photosystems have very effective light harvesting processes, simultaneously preventing photosynthetic photo-oxidative damage. This may occur during periods of intense light, and photosynthetic organisms have evolved different defensive mechanisms to cope with it (Jahns \& Holzwarth, 2012; Faisal, Ibreesam et al., 2020). There are two key pathways for chloroplasts: electron transfer to molecular oxygen leading to the formation of $\mathrm{O}_{2}, \mathrm{H}_{2} \mathrm{O}_{2}$ and hydroxyl radicals (O percent $\mathrm{H})$ (Halliwell, 2007), and a second pathway involving the transfer of energy from triplet chlorophyll to molecular oxygen leading to the formation of superoxide radicals $\left(\mathrm{O}_{2}^{-}\right)$ (Nunes et al., 2019).

In plants, $\mathrm{O}_{2}^{-}$is naturally generated during photosynthesis in chloroplasts, particularly when plants develop under conditions of environmental stress that inhibit photosynthetic processes, causing excessive absorption of light energy (Nunes et al., 2019; Faisal, Jasim, Naji, Naushad \& Ahamad, 2021).

Meropenem is believed to interfere with the electron transport chain leading to the formation of oxidized chlorophyll triplets capable of transferring energy directly to the $\mathrm{O}_{2}$ molecule, which in turn has a dual effect on plant cells resulting in the oxidation of biomolecules, including lipids (which are structural elements of the cell membranes), but also proteins with a dual effect on plant cells (Ramel et al., 2012; Faisal \& Naji, 2019).

However, can ultimately endanger the normal physiology of plants. That is why defensive/adaptive mechanisms among plant species are highly elaborate. Catalase is a key enzyme that plays an essential role in the degradation of hydrogen peroxide. This enzyme serves as a protector for the species against the deleterious oxidant effects that can be caused by this chemical (Nunes, Verde $\&$ Soares, 2015).

In cells, catalase is still involved to prevent damage caused by the normal formation of $\mathrm{H}_{2} \mathrm{O}_{2}$ during aerobic processes that are part of the cell's physiological activity. An rise in the levels of hydrogen peroxide is overserved, but due to the metabolism mechanism of certain chemicals, it may result from the occurrence of oxidative stress. This is immediately followed by increased catalase activity, which acts as a physiological compensation during conditions of oxidative stress (Nunes et al., 2019) according to Gomes et al. (2017). There was a noticeable increase in peroxide concentration and a large increase in catalase activity in minor plants after $0.75 \mathrm{mg} \cdot \mathrm{L}^{-1}$ of ciprofloxacin was exposed for one week. These data agree with the pattern that has been collected here. This data set indicates that biomolecules are influenced by reactive oxygen species that ultimately result from Meropenem's metabolism.

\section{Chemical oxygen demand (COD) and root length}

By weighing COD, the content of organic matter was determined. A commercial Hach package (2125915 COD HR) was added to this purpose, according to the US EPA System 410.4 (EPA, 1993). This process relies on the oxidation of the organic compounds, which has been quantified at $610 \mathrm{~nm}$ based on the potential to reduce the dichromate ion to chroma ions. A multiparametric Hanna 


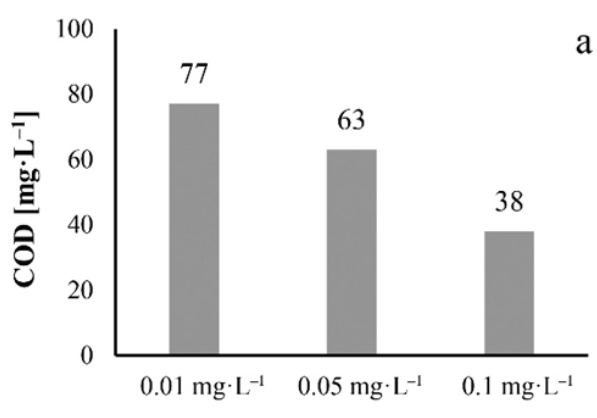

Initial concentration $\left[\mathrm{mg} \cdot \mathrm{L}^{-1}\right]$

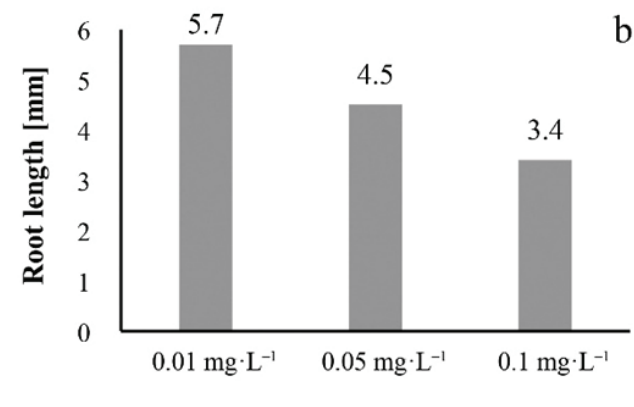

Initial concentration $\left[\mathrm{mg} \cdot \mathrm{L}^{-1}\right]$

FIGURE 2. The removal efficiencies of chemical oxygen demand (COD) and root length with different initial concentration $\left(0.01,0.05\right.$ and $\left.0.1 \mathrm{mg} \cdot \mathrm{L}^{-1}\right)$ for Meropenem in CW of Lemna spp.

spectrophotometer (HI 83214 model) was used to evaluate the absorbance values that precisely fit $\mathrm{COD}\left(\mathrm{mg} \cdot \mathrm{L}^{-1}\right)$ levels. The parameters evaluated for varying concentrations and the removal increases were found in the raw material with reduced concentration for the chemical oxygen (Fig. 2).

\section{Kinetics of biodegradation}

Kinetic is a critical factor for understanding the biodegradation process, calculating the speed of bioremediation and creating effective clean up for a polluted area. A set of empirically derived rate laws is the kinetics of biodegradation. The three lists in Table 1 are enough to explain most biological reactions.

Using zero-order, first-order, second-order and Grau kinetic models, the removal data is represented. In order to achieve non-linear fitting, zero-order, first-order and second-order kinetic models have a small application for bio removal of various Meropenem concentrations by applying the "solver" option in Excel 2016. In order to analyze the kinetics for biodegradation processes, the final concentration to intial concentration of Meropenem in the sand was also plotted against time as shown in the figure. The biodegradation kinetics of kerosene were analyzed using the kinetic models described in Figures $3 \mathrm{a}, 3 \mathrm{~b}$ and $3 \mathrm{c}$ for $0.01,0.05$ and $0.1 \mathrm{mg} \cdot \mathrm{L}^{-1}$, respectively.

Although there was not a very strong agreement with the experimental data in the zero-order, first-order, and secondorder models, the Grau model showed a very good contrast to the collected experimental data.

TABLE 1. Mathematical kinetic models

\begin{tabular}{|l|c|}
\hline Model & Mathematical formula \\
\hline Zero order & $C=C \cdot-k t$ \\
\hline First order & $C=C \cdot e^{-k t}$ \\
\hline Second order & $C=\frac{C}{1+C \cdot k t}$ \\
\hline Grau & $C=C \cdot\left(1-\frac{1}{b+\frac{a}{t}}\right)$ \\
\hline
\end{tabular}


a) $0.01 \mathrm{~m} \cdot \mathrm{L}^{-1}$

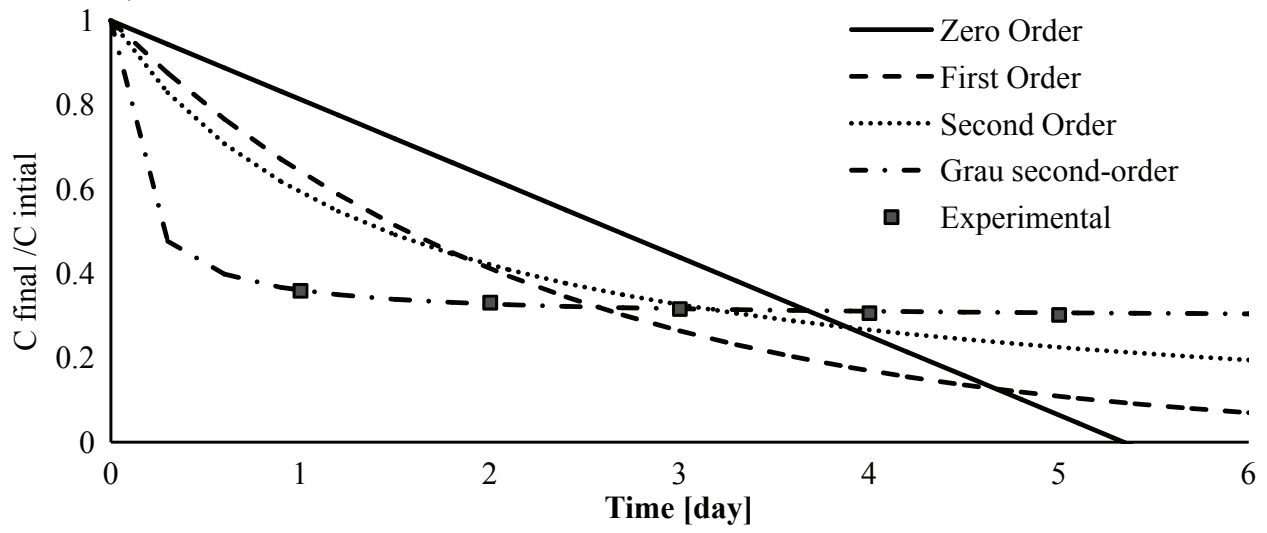

b) $0.05 \mathrm{~m} \cdot \mathrm{L}^{-1}$

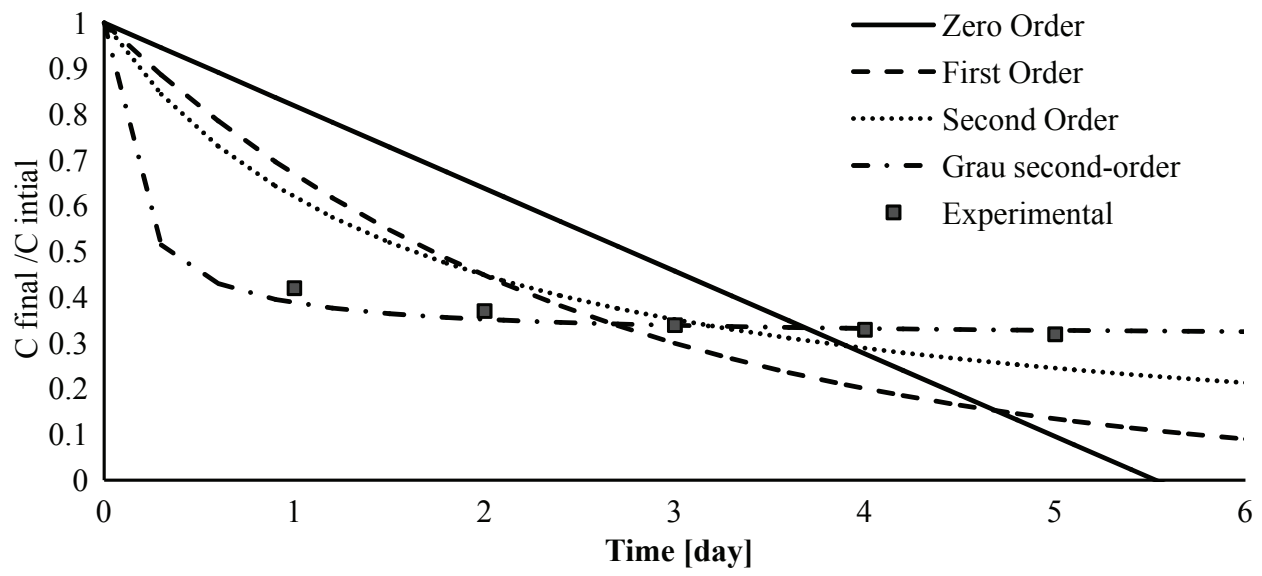

c) $0.1 \mathrm{~m} \cdot \mathrm{L}^{-1}$

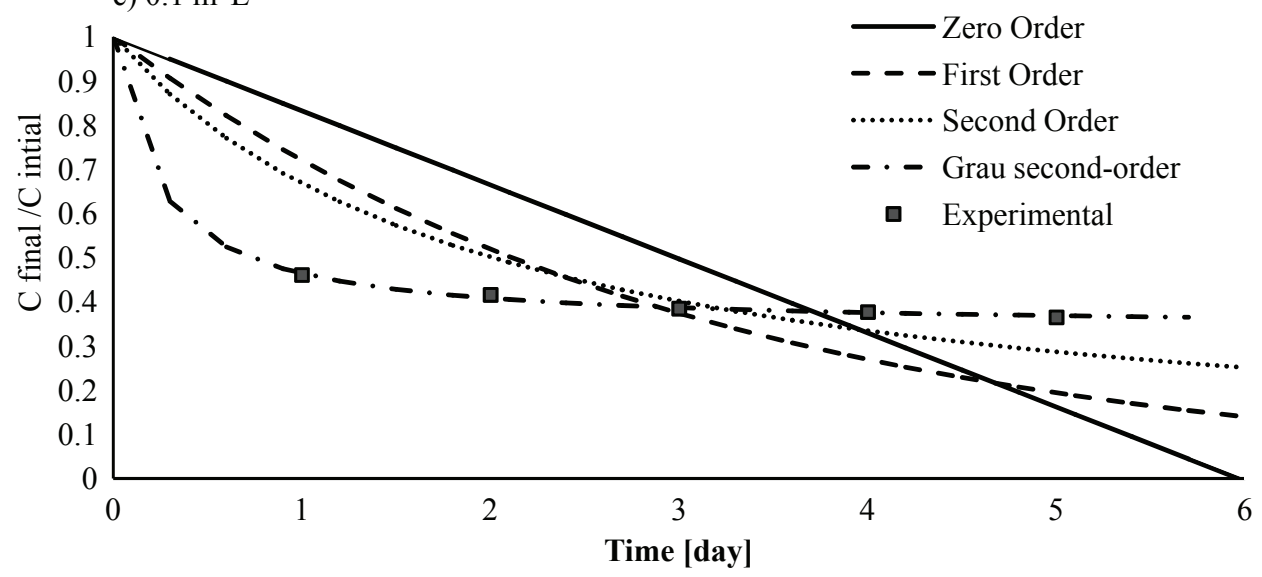

FIGURE 3. Kinitic model of plant system for different initial concentration $\left(0.01,0.05\right.$ and $\left.0.1 \mathrm{mg} \cdot \mathrm{L}^{-1}\right)$ 
Compared to other methods, the information collected separately for each of the kinetic models from the slopes of plots indicates a strong compliance with the second-order model. In Table 2, however, all constants resulting from fitting with $R^{2}$ and SSE were added. The listed figures show that there is a satisfactory correspondence between experimental results and model predictions, as is evident from the $S S E$ values in combination with $R^{2}$. options currently available to the petrochemical industry.

This research has shown that Lemna minor, an invasive aquatic plant abundant in surface waters throughout the world, has a great potential to ecologically remediate and extract a large amount of Meropenem from polluted waters. The plant was able to absorb and degrade Meropenem from wetlands. However, it was not possible to completely elucidate these processes due to the uncertainty

TABLE 2. Parameter of kinetics model for plant system

\begin{tabular}{|l|c|c|c|c|}
\hline \multirow{3}{*}{ Model } & \multirow{2}{*}{ Parameter } & \multicolumn{3}{|c|}{ Intial concentration $\left[\mathrm{mg} \cdot \mathrm{L}^{-1}\right]$} \\
\cline { 3 - 5 } & & 0.01 & 0.05 & 0.1 \\
\hline \multirow{3}{*}{ First order } & $k$ & 0.4440 & 0.4020 & 0.3278 \\
\cline { 2 - 5 } & $R^{2}$ & 0.9954 & 0.9846 & 0.9779 \\
\cline { 2 - 5 } & $S S E$ & 0.0000 & 0.0003 & 0.0012 \\
\hline \multirow{3}{*}{ Second order } & $k$ & 68.8890 & 12.3272 & 4.9683 \\
\cline { 2 - 5 } & $R^{2}$ & 0.9982 & 0.9924 & 0.9901 \\
\cline { 2 - 5 } & $S S E$ & 0.0000 & 0.0000 & 0.0002 \\
\cline { 2 - 5 } & $k$ & 0.0019 & 0.0090 & 0.0168 \\
\cline { 2 - 5 } & $R^{2}$ & 0.9034 & 0.8843 & 0.8964 \\
\hline \multirow{3}{*}{ Grau } & $S S E$ & 0.0000 & 0.0007 & 0.0026 \\
\cline { 2 - 5 } & $a$ & 0.1496 & 0.1823 & 0.3525 \\
\cline { 2 - 5 } & $b$ & 1.4128 & 1.4509 & 1.5138 \\
\cline { 2 - 5 } & $R^{2}$ & 0.9835 & 0.9878 & 0.9850 \\
\hline
\end{tabular}

\section{Conclusions}

The treatment of contaminated wetlands with Meropenem using traditional methods attracts concern from some parts of society, while ecological approaches are considered with minimal of the fate and the transformation/mineralization processes of Meropenem by Lemna minor. For $0.01,0.05$ and $0.1 \mathrm{mg} \cdot \mathrm{L}^{-1}$ influential concentration, the variation of effluent concentration with hydraulic retention time for all units under consideration was well defined by 
the Grau second-order kinetic model. It is therefore suggested that studies should be carried out to explain the underlying mechanisms of degradation, conversion and mineralization by Lemna minor of Meropenem.

\section{References}

Abd Ali, Z.T., Naji, L.A., Almuktar, S.A., Faisal, A.A., Abed, S.N., Scholz, M., Naushad, M. \& Ahamad, T. (2020). Predominant mechanisms for the removal of nickel metal ion from aqueous solution using cement kiln dust. Journal of Water Process Engineering, 33, 101033. https://doi.org/10.1016/ j.jwpe.2019.101033

Ahmed, D.N., Faisal, A.A., Jassam, S.H., Naji, L.A. \& Naushad, M. (2020). Kinetic model for $\mathrm{pH}$ variation resulted from interaction of aqueous solution contaminated with nickel ions and cement kiln dust. Journal of Chemistry, 2020, 8732308. https://doi. org/10.1155/2020/8732308

Ahmed, D.N., Naji, L.A., Faisal, A.A., Al-Ansari, N. \& Naushad, M. (2020). Waste foundry sand/MgFe-layered double hydroxides composite material for efficient removal of Congo red dye from aqueous solution. Scientific Reports, 10(1), 1-12.

Alshammari, M., Al Juboury, M.F., Naji, L.A., Faisal, A.A., Zhu, H., Al-Ansari, N. \& Naushad, M. (2020). Synthesis of a novel composite sorbent coated with siderite nanoparticles and its application for remediation of water contaminated with Congo red dye. International Journal of Environmental Research, 14, 177-191.

Baker, N.R. (2008). Chlorophyll fluorescence: a probe of photosynthesis in vivo. Annual Review of Plant Biology, 59, 89-113.

Białk-Bielińska, A., Matzke, M., Caban, M., Stolte, S., Kumirska, J. \& Stepnowski, P. (2018). Effects of five sulphonamides on duckweed (Lemna minor) after prolonged exposure time and their dependency on photoradiation. Science of the Total Environment, 618, 952-960.
Faisal, A.A., Alquzweeni, S.S., Naji, L.A. \& Naushad, M. (2020). Predominant mechanisms in the treatment of wastewater due to interaction of benzaldehyde and iron slag byproduct. International Journal of Environmental Research and Public Health, 17(1), 226. https://doi.org/10.3390/ijerph17010226

Faisal, A.A., Al-Wakel, S.F., Assi, H.A., Naji, L.A. \& Naushad, M. (2020). Waterworks sludge-filter sand permeable reactive barrier for removal of toxic lead ions from contaminated groundwater. Journal of Water Process Engineering, 33, 101112. https://doi. org/10.1016/j.jwpe.2019.101112

Faisal, A.A., Ibreesam, M.M., Al-Ansari, N., Naji, L.A., Naushad, M. \& Ahamad, T. (2020). COMSOL multiphysics 3.5 a package for simulating the cadmium transport in the sand bed-bentonite low permeable barrier. Journal of King Saud University - Science, 32(3), 1944-1952.

Faisal, A.A., Jasim, H.K., Naji, L.A., Naushad, M. \& Ahamad, T. (2021). Cement kiln dust-sand permeable reactive barrier for remediation of groundwater contaminated with dissolved benzene. Separation Science and Technology, 56(5), 870-883.

Faisal, A.A. \& Naji, L.A. (2019). Simulation of ammonia nitrogen removal from simulated wastewater by sorption onto waste foundry sand using artificial neural network. Association of Arab Universities Journal of Engineering Sciences, 26(1), 28-34.

Faisal, A.A., Nassir, Z.S., Naji, L.A., Naushad, M. \& Ahamad, T. (2020). A sustainable approach to utilize olive pips for the sorption of lead ions: numerical modeling with aid of artificial neural network. Sustainable Chemistry and Pharmacy, 15, 100220. https://doi. org/10.1016/j.scp.2020.100220

Girardi, C., Greve, J., Lamshöft, M., Fetzer, I., Miltner, A., Schäffer, A. \& Kästner, M. (2011). Biodegradation of ciprofloxacin in water and soil and its effects on the microbial communities. Journal of Hazardous Materials, 198, 22-30.

Gomes, M.P., Gonçalves, C.A., Brito, J.C.M. de, Souza, A.M., Silva Cruz, F.V. da, Bicalho, E.M., Figueredo, C.C. \& Garcia, Q.S. (2017). Ciprofloxacin induces oxidative stress in duckweed (Lemna minor L.): implications 
for energy metabolism and antibiotic-uptake ability. Journal of Hazardous Materials, 328, 140-149.

Halliwell, B. (2007). Biochemistry of oxidative stress. Biochemical Society Transactions, 35, 1147-1150.

Jahns, P. \& Holzwarth, A.R. (2012). The role of the xanthophyll cycle and of lutein in photoprotection of photosystem II. Biochimica et Biophysica Acta (BBA) - Bioenergetics, 1817(1), 182-193.

Karthikeyan, K.G. \& Meyer, M.T. (2006). Occurrence of antibiotics in wastewater treatment facilities in Wisconsin, USA. Science of the Total Environment, 361(1-3), 196-207.

Kouki, S., M'hiri, F., Saidi, N., Belad'd, S. \& Hassen, A. (2009). Performances of a constructed wetland treating domestic wastewaters during a macrophytes life cycle. Desalination, 246(1-3), 452-467.

Naji, L.A., Faisal, A.A., Rashid, H.M., Naushad, M. \& Ahamad, T. (2020). Environmental remediation of synthetic leachate produced from sanitary landfills using low-cost composite sorbent. Environmental Technology \& Innovation, 18, 100680. https://doi. org/10.1016/j.eti.2020.100680

Naji, L.A., Jassam, S.H., Yaseen, M.J., Faisal, A.A. \& Al-Ansari, N. (2020). Modification of Langmuir model for simulating initial $\mathrm{pH}$ and temperature effects on sorption process. Separation Science and Technology, 55(15), 2729-2736.

Nunes, B., Veiga, V., Frankenbach, S., Serôdio, J. \& Pinto, G. (2019). Evaluation of physiological changes induced by the fluoroquinolone antibiotic ciprofloxacin in the freshwater macrophyte species Lemna minor and Lemna gibba. Environmental Toxicology and Pharmacology, 72, 103242. https://doi. org/10.1016/j.etap.2019.103242

Nunes, B., Verde, M.F. \& Soares, A.M. (2015). Biochemical effects of the pharmaceutical drug paracetamol on Anguilla anguilla. Environmental Science and Pollution Research, 22(15), 11574-11584.

Phillips, I. (2003). Does the use of antibiotics in food animals pose a risk to human health? A critical review of published data. Journal of Antimicrobial Chemotherapy, 53, 28-52.
Rahi, M.A., Faisal, A.A., Naji, L.A., Almuktar, S.A., Abed, S.N. \& Scholz, M. (2020). Biochemical performance modelling of non-vegetated and vegetated vertical subsurface-flow constructed wetlands treating municipal wastewater in hot and dry climate. Journal of Water Process Engineering, 33, 101003. https://doi.org/10.1016/j.jwpe.2019.101003

Rakhshaee, R., Giahi, M. \& Pourahmad, A. (2009). Studying effect of cell wall's carboxyl-carboxylate ratio change of Lemna minor to remove heavy metals from aqueous solution. Journal of Hazardous Materials, 163(1), 165-173.

Ramel, F., Birtic, S., Ginies, C., Soubigou-Taconnat, L., Triantaphylidčs, C. \& Havaux, M. (2012). Carotenoid oxidation products are stress signals that mediate gene responses to singlet oxygen in plants. Proceedings of the National Academy of Sciences, 109(14), 5535-5540.

Saad, N., Abd Ali, Z.T., Naji, L.A., Faisal, A.A.A.H. \& Al-Ansari, N. (2020). Development of Bi-Langmuir model on the sorption of cadmium onto waste foundry sand: effects of initial $\mathrm{pH}$ and temperature. Environmental Engineering Research, 25(5), 677-684.

Sekulic, M.T., Boskovic, N., Slavkovic, A., Garunovic, J., Kolakovic, S. \& Pap, S. (2019). Surface functionalised adsorbent for emerging pharmaceutical removal: adsorption performance and mechanisms. Process Safety and Environmental Protection, 125, 50-63.

Thiele-Bruhn, S. (2003). Pharmaceutical antibiotic compounds in soils - a review. Journal of Plant Nutrition and Soil Science, 166(2), 145-167.

Verma, R. \& Suthar, S. (2015). Lead and cadmium removal from water using duckweed - Lemna gibba L.: Impact of $\mathrm{pH}$ and initial metal load. Alexandria Engineering Journal, 54(4), 1297-1304.

Zhao, J.L., Ying, G.G., Liu, Y.S., Chen, F., Yang, J.F., Wang, L., Yang, Y.B., Stauber, J.L. \& Warne, M.S.J. (2010). Occurrence and a screeninglevel risk assessment of human pharmaceuticals in the Pearl River system, South China. Environmental Toxicology and Chemistry, 29(6), 1377-1384. 


\section{Summary}

Removal of Meropenem by using Lemna minor. In this paper we presented a case study about the removal of a pharmaceutical contamination (in this case Meropenem) from the environment using organic natural substance (in this case study is Lemna minor). The study proved the efficiency of the used material to remove the contamination of three specific contamination levels of Meropenem. The experimental testing proved the concept, the effect on two vital measures (the chemical oxygen demand-COD, and the root length), which showed improvement in both measures. The degradation mechanism was proven to be not arbitrary by testing the degradation behavior measured practically to four kinetic models. The practical work was found to fit perfectly with the Grau second order model as the simulation work included in the paper shows. Based on this study it can be proven that the dangerous chemicals resulted from the residue of a pharmaceutical substances can be removed efficiently using a totally natural environmental friendly material.

\footnotetext{
Authors' address:

Noora Saad - corresponding author Al-Nahrain University

College of Engineering

Civil Engineering Department

Al-Jadiriyah, 64074 Baghdad

Iraq

e-mail: nano_8098@yahoo.com

Samara Al-Dulaimi

University of Zakho

Faculty of Science

Department of Environmental Sciences

Zakho International Road, 12 Duhok

Kurdistan Region

Iraq
} 